Article

\title{
Ammonia Volatilization Reduced by Combined Application of Biogas Slurry and Chemical Fertilizer in Maize-Wheat Rotation System in North China Plain
}

\author{
Md Arifur Rahaman ${ }^{1,+} \oplus$, Xiaoying Zhan ${ }^{1,+}$, Qingwen Zhang ${ }^{1, *}$, Shuqin $\mathrm{Li}^{2}$, Shengmei Lv ${ }^{2}$, \\ Yuting Long ${ }^{2}$ and Hailing Zeng ${ }^{2}$ \\ 1 Institute of Environment and Sustainable Development in Agriculture, Chinese Academy of \\ Agricultural Sciences, Beijing 100081, China; 2017y90100077@caas.cn (M.A.R.); zhanxiaoying@caas.cn (X.Z.) \\ 2 College of Water Resources and Civil Engineering, China Agricultural University, Beijing 100081, China; \\ lishuqin@cau.edu.cn (S.L.); 2018309080206@cau.edu.cn (S.L.); 2018309080228@cau.edu.cn (Y.L.); \\ 2018309080222@cau.edu.cn (H.Z.) \\ * Correspondence: zhangqingwen@caas.cn; Tel.: +86-10-82106031 \\ + The authors contributed equally to this work.
}

Received: 27 April 2020; Accepted: 22 May 2020; Published: 27 May 2020

check for updates

\begin{abstract}
Digestate and biogas slurry (BS) are the byproduct of biogas engineering that could be used for elevating plant growth. However, the consequent emissions of ammonia from BS are considered a severe threat to the atmosphere. Herein, we conducted two consecutive field experiments with wheat-maize rotations to find out the optimum ratio of BS to combine with chemical fertilizer $(\mathrm{CF})$ to reduce ammonia volatilization $(\mathrm{AV})$ while keeping the stable crop yield. In maize season, $226.5 \mathrm{~kg} \mathrm{~N} / \mathrm{ha}$ of CF was applied. In wheat season, $226.5 \mathrm{~kg} \mathrm{~N} / \mathrm{ha}$ was applied at different ratios $(100 \%$, $80 \%$, and $50 \%$ ) between BS and CF. Our results found that the maximum yield of $6250 \mathrm{~kg} / \mathrm{ha}$ was produced by $\mathrm{CF}$, and this yield could be obtained through a combined application of $38 \% \mathrm{BS}$ mixed with CF. Highest AV produced of $16.08 \mathrm{~kg} / \mathrm{ha}$ by CF. BS treatments significantly reduced the emission from $18 \%$ to $32 \%$ in comparison to CF. The combined application of BS-CF produced the highest yield due to essential nutrients coming from both BS-CF. Subsequently, it reduced the AV depending on fertilizer type and fertilizer rate. An optimal ratio of $38 \%$ BS was recommended to produce the highest yield and lowest ammonia emissions. The application of BS together with different ratios of $\mathrm{CF}$ could be an alternative agricultural strategy to obtain desired crop yield and reduce AV in North China Plain (NCP).
\end{abstract}

Keywords: digestate; biogas slurry; chemical fertilizer; ammonia volatilization; crop yield; ratio; field experiment

\section{Introduction}

China is one of the major agricultural countries and provides nearly one-fifth of calories to humans worldwide [1]. There is high application of chemical nitrogen $(\mathrm{N})$ fertilizer in the agricultural field to achieve high crop yield. The two main agricultural production systems in China are winter wheat and summer maize, that are grown annually. NCP is a hotspot of N input and N loss in China [2]. $\mathrm{CF}$ inputs have kept on increasing and have been far higher than crop demand in the NCP [3,4]. Data show that the Nitrogen Use Efficiency (NUE) of NCP is less than $39.6 \%$, which means more than $60-70 \%$ of CF applied is often misused [4]. Excessive use of CF has caused severe environmental degradation [5]. Large amounts of $\mathrm{N}$ fertilizer are lost to the environment through $\mathrm{N}$ runoff, leaching, 
denitrification, and $\mathrm{AV}$. $\mathrm{AV}$ is the major pathway of $\mathrm{N}$ loss [6]. In China, about $30 \%$ of $\mathrm{N}$ loss occurs via $\mathrm{NH}_{3}$ emission [7]. Ammonia is the main component of soluble alkaline gas in the atmosphere and has a significant effect on local air quality [5,8-14]. It can travel long distances before being converted into fine particles [15]. The deposition of ammonia causes severe environmental impacts on terrestrial and aquatic systems through eutrophication, reduced soil $\mathrm{pH}$, and nutrient imbalances [16]. Consequently, ammonia deposition negatively affects living organisms [12,17-20]. Therefore, mitigation of $\mathrm{NH}_{3}$ emission from the cropland system is urgent for environmental protection. Taking food security and environmental friendliness into account, many studies have shown that the combination of organic fertilizers and CFs could concurrently improve soil productivity as well as yield. Livestock number in China has been increased dramatically in the last two decades. As a result, the amount of manure produced by livestock has increased significantly. Recent studies have shown that approximately $3600 \mathrm{Mt}$ of fresh weight manure is produced annually [21]. From a significant amount of manure, about $80 \%$ is applied to the field, and the rest of $20 \%$ is left unmanaged [22]. The large amounts of manure waste released by the livestock farms can have a negative effect on the environment, unless properly unmanaged. Anaerobic digestion of manures for produce biogas digestate is of great use for livestock manure management [23]. BS is the by-product of biogas digestate and considered a good source of macro and micronutrients [24]. BS can be used to substitute the chemical fertilizer because of the high amount of nutrients concentration, including N, P, K, Zn, Mn, and B [25-29]. In general, the application of only $\mathrm{CFs}$ could decline soil fertility and enhance $\mathrm{NH}_{3}$ emissions. The use of digestate slurry from anaerobic digestion as fertilizer in crop production is an important strategy for minimizing $\mathrm{NH}_{3}$ emissions. However, sole application of organic fertilizer could only reduce $\mathrm{NH}_{3}$ emission, but the desired crop yield cannot be achieved [30]. Some studies showed that crop productivity could be significantly increased if slurry is applied together with CF [31,32]. For this reason, the optimum ratio of $\mathrm{BS}$ and $\mathrm{CF}$ should be developed to simultaneously reduce the loss of $\mathrm{N}$ through $\mathrm{AV}$, and improve the crop yield of summer maize and winter wheat rotation system. However, the transportation of digestate slurry on fields is an uneconomical option for farmers. Furthermore, the oversupply of digestate in areas with intensive biogas plants is a major environmental concern. It has been demonstrated that over application of digestate can be avoided under controlled conditions, and it is an environmentally promising option still now, in spite of being an expensive option for farmers [33].

Therefore, this study aims to investigate the effects of BS treatments on the maize-wheat rotation crops and find out how to substitute the CF with a mix of CF and BS. The experiment was conducted in the field and the ammonia volatilization from different application ratios of BS and CF was evaluated. Furthermore, this study investigated how the AV kept minimum emissions, whether it is environmentally friendly or not. Hence, the following hypotheses were evaluated in this experiment (1) BS cannot increase crop yield constantly (2) BS can partially substitute CF and could simultaneously reduce the $\mathrm{AV}$ and improve crop yield.

\section{Materials and Methods}

\subsection{Experimental Design}

The experiment was carried out from June 2018 to June 2019 at Zhongyu Ecological Industrial Park, Binzhou City, Shandong Province $\left(37^{\circ} 22^{\prime} \mathrm{N}, 118^{\circ} 01^{\prime} \mathrm{E}\right)$. The climate of the area is a temperate continental monsoon with an average temperature of $12.7^{\circ} \mathrm{C}$, the average sunshine hours are $2632 \mathrm{~h}$, and the annual average precipitation is $564.8 \mathrm{~mm}$. The soil type is saline-alkaline soil. The basic physical and chemical properties of the soil before the test in 2018 are shown below (Table 1).

In NCP, the essential agricultural production system is winter wheat-summer maize rotation. These two crops, winter wheat and summer maize, are simultaneously growing in one year. Before sowing, we cleaned all the crop residuals and prepared the land by harrowing. A total of four treatments (Table 2) were set up for the test, along with three replicates per treatment. A total of 
12 cells, each cell area was $14 \mathrm{~m} \times 10 \mathrm{~m}=140 \mathrm{~m}^{2}$. The crop planting method in the test area was summer maize-winter wheat rotation. Summer maize was planted on 22 June 2018 and harvested in week of October 2018. With every treatment, the total nitrogen application rate in the maize season included $226.5 \mathrm{~kg} \mathrm{~N} \mathrm{ha}^{-1}$ which was split into two parts, one at the time of sowing as basal fertilizer at $174 \mathrm{~kg} \mathrm{~N} \mathrm{ha}^{-1}$ where $69 \mathrm{~kg} \mathrm{~N}$ was from urea and $105 \mathrm{~kg} \mathrm{~N}$ from Diammonium Phosphate (DAP). The other application was conducted at the jointing stage named tillering, at $52.5 \mathrm{~kg} \mathrm{ha}^{-1}$. The total phosphorus application rate in the maize season was $322.5 \mathrm{~kg} \mathrm{P}_{2} \mathrm{O}_{5} \mathrm{ha}^{-1}$ as basal fertilizer. The water input in the maize season depended on natural rainfall. Winter wheat was planted on 9 October 2018 and harvested on 3 June 2019. With every treatment, the total nitrogen application rate in the winter wheat season was $226.5 \mathrm{~kg} \mathrm{ha}^{-1}$, which was split into two parts. The first one at the sowing time was $68 \mathrm{~kg} \mathrm{ha}^{-1}$, or one-third of the total, used as basal fertilizer, and the rest $158 \mathrm{~kg} \mathrm{ha}^{-1}$ included both BS and CF. The application amount is shown in Table 2. The BS (digestion substrate: Pig manure) was provided by Zhongyu Ecological Industrial Park near the field. The physical and chemical properties of BS are mentioned in Table 3.

Table 1. Physical and chemical properties of the soil.

\begin{tabular}{ccccccc}
\hline Layer & $\begin{array}{c}\text { Organic Matter } \\
\left(\mathbf{g ~ k g}^{-1}\right)\end{array}$ & $\begin{array}{c}\text { Total } \mathbf{~} \\
\left(\mathbf{g ~ k g}^{-1}\right)\end{array}$ & $\begin{array}{c}\text { Total K } \\
\left(\mathbf{g ~ k g}^{-1}\right)\end{array}$ & $\begin{array}{c}\text { Available P } \\
\left(\mathbf{m g ~ k g}^{-\mathbf{1}}\right)\end{array}$ & $\begin{array}{c}\text { Available N } \\
\left(\mathbf{m g ~ k g}^{-\mathbf{1}}\right)\end{array}$ & $\begin{array}{c}\text { Available K } \\
\left(\mathbf{m g ~ k g}^{-\mathbf{1}} \mathbf{)}\right.\end{array}$ \\
\hline $0-20 \mathrm{~cm}$ & 13.7 & 0.9 & 21 & 70.6 & 83.4 & 227.0 \\
\hline $20-40 \mathrm{~cm}$ & 10.7 & 0.6 & 21 & 22.0 & 46.5 & 146.9 \\
\hline
\end{tabular}

Table 2. Different ratios of BS and chemical fertilizer in wheat season.

\begin{tabular}{|c|c|c|c|c|c|c|c|c|c|c|c|}
\hline Fertilizer Type & & T1 & T3 & T6 & CK & Fertilizer Type & & T1 & T3 & T6 & CK \\
\hline \multirow{2}{*}{$\begin{array}{c}\text { Basal } \\
\text { Fertilization }\end{array}$} & $\mathrm{CF}, \mathrm{k} / \mathrm{ha}$ & 68 & 68 & 68 & 68 & \multirow{2}{*}{$\begin{array}{l}\text { Tillering } \\
\text { Fertilization }\end{array}$} & $\mathrm{CF}, \mathrm{Kg} / \mathrm{ha}$ & 0 & 79 & 126 & 158 \\
\hline & $\mathrm{BS}, \mathrm{kg} / \mathrm{ha}$ & 0 & 0 & 0 & 0 & & $\mathrm{BS}, \mathrm{Kg} / \mathrm{ha}$ & 158 & 79 & 32 & 0 \\
\hline
\end{tabular}

Note: T1, T3, T6, and CK represent the different treatments. Basal fertilization: $68 \mathrm{Kg} \mathrm{N} /$ ha was used in every treatment. Tillering fertilization: T1: $0 \mathrm{CF}+158 \mathrm{BS}, \mathrm{T} 3: 79 \mathrm{CF}+79 \mathrm{BS}, \mathrm{T} 6: 126 \mathrm{CF}+32 \mathrm{BS}$, CK: $158 \mathrm{CF}+0 \mathrm{BS}$. Different numbers indicate different fertilization rates, $\mathrm{Kg} \mathrm{N} / \mathrm{ha}$. Where, CF: Chemical fertilizer, BS: Biogas slurry.

Water was irrigated in the greening period (28 November) and springtime (1 March). BS was irrigated at the second time. BS mixed with water to prepare different ratios was irrigated, which is mentioned in Table 2. Sufficient water was irrigated during that time. Slurry and water irrigation rate was $2500 \mathrm{~m}^{3} /$ ha. The total phosphorus application rate in the wheat season was $322.5 \mathrm{~kg} \mathrm{P}_{2} \mathrm{O}_{5} \mathrm{ha}^{-1}$ and was used as basal fertilizer. The remaining management measures, such as weeding and pest control, are consistent with local farmland management methods.

Table 3. Physio-chemical properties of the biogas slurry.

\begin{tabular}{ccccccccccccccc}
\hline Parameter & $\mathbf{p H}$ & $\mathbf{T N}$ & $\mathbf{C O D}$ & $\mathbf{N H}_{4}{ }^{+} \mathbf{N}$ & $\mathbf{N O}_{3}{ }^{-} \mathbf{N}$ & $\mathbf{T P}$ & $\mathbf{T K}$ & $\mathbf{F e}$ & $\mathbf{A s}$ & $\mathbf{H g}$ & $\mathbf{C u}$ & $\mathbf{Z n}$ & $\mathbf{C d}$ & $\mathbf{P b}$ \\
\hline Value & 8 & 1710 & 8713 & 1558 & 0.081 & 300 & 1390 & 4.50 & 5.26 & 0.09 & 103 & 877 & 0.17 & 3.61 \\
\hline \multicolumn{8}{c}{ Note: $\left(\mathrm{COD}, \mathrm{TN}, \mathrm{NH}_{4}{ }^{+} \mathrm{N}, \mathrm{NO}_{3}{ }^{-} \mathrm{N}, \mathrm{TP}, \mathrm{TK}, \mathrm{Fe}\right)$} & $\mathrm{unit}, \mathrm{mg} / \mathrm{L}$ and $(\mathrm{As}, \mathrm{Hg}, \mathrm{Cu}, \mathrm{Zn}, \mathrm{Cd}, \mathrm{Pb})$ & $\mathrm{unit}, \mu \mathrm{g} / \mathrm{L}$. &
\end{tabular}

\subsection{Measurement of $A V$}

The dynamic chamber was applied to measure $\mathrm{NH}_{3}$ fluxes from summer maize and winter wheat field. The device consisted of a dynamic chamber, a vacuum pump, and an acid trap to collect $\mathrm{NH}_{3}$ gas. A vent pipe was connected to the chemical trap bottle and another part connected to the plastic to form a confined space (Figure 1). The cylindrical dynamic chamber was made of poly-methyl methacrylate with an inner diameter of $20 \mathrm{~cm}$ and a height of $5 \mathrm{~cm}$. The vent pipe was held at a height of about $2.5 \mathrm{~m}$ above the ground surface. During the collecting time, a piece of sponge was put on the top of the vent pipe. Before putting sponge into the vent pipe, the sponge must be wetted by diluted sulfuric acid. 
Then the cover was placed on the base and the base was sealed with pure water to make it air tight. A chemical trap bottle filled with $60 \mathrm{~mL}$ of $0.01 \mathrm{M} \mathrm{H}_{2} \mathrm{SO}_{4}$ connected to one hole was used to collect $\mathrm{NH}_{3}$ gas from the top vent pipe and the other end was connected to the flowmeter. The air exchange rate through the chamber was set to $20 \mathrm{~L} \mathrm{~min}^{-1}$. The rubber plug of the flowmeter without the valve was inserted into one end of the PVC tube, and the other end of the PVC tube was connected to the vacuum pump. The airtightness of each latex tube connection, the metal head of the flowmeter, and the vacuum pump was thoroughly checked. The three pumps were properly connected to the power supply separately. The main switch was turned on and the flow rate of the flowmeter was adjusted to $20 \mathrm{~L} \mathrm{~min}^{-1}$. At the end of the hour, the pump switch was turned off. The acid absorption liquid bottle must be covered with red plug during transport to the field and back to the laboratory from the field. Immediately after the acid was returned to the laboratory, it was poured into a clean (purified water rinsed) plastic tube. The plastic tube must be numbered. The plastic bottles were stored at room temperature in the sampling order. $\mathrm{NH}_{3}$ volatilization was measured twice per day during the whole week after fertilization and one day every two weeks during other times. The $\mathrm{NH}_{3}$ volatilization rate was measured twice daily: Morning (9:00-11:00 a.m.) and afternoon (16:00-18:00 p.m.). The $\mathrm{NH}_{4}{ }^{+}-\mathrm{N}$ concentration in the acid trap was titrated with $0.01 \mathrm{~mol} \mathrm{~L}^{-1}$ standard diluted sulfuric acid solution [18,34]. The $\mathrm{NH}_{3}$ emission flux from maize-wheat fields was calculated according to the following equation:

$$
\mathrm{VNi}=(\mathrm{C} 1 \mathrm{i} \times \mathrm{V} 1 \mathrm{i}+\mathrm{C} 2 \mathrm{i} \times \mathrm{V} 2 \mathrm{i}) \times \frac{14 \times 001}{\pi \times R^{2} \times t} \times 12
$$

where $\mathrm{V}_{\mathrm{Ni}}$ represents the $\mathrm{NH}_{3}$ volatilization flux $\left(\mathrm{Kg} \mathrm{ha}^{-1} \mathrm{~d}^{-1}\right)$ at day $\mathrm{i}, \mathrm{C}_{1 \mathrm{i}}$ and $\mathrm{C}_{2 \mathrm{i}}$ are the concentration of $\mathrm{H}_{2} \mathrm{SO}_{4}\left(\mathrm{~mol} \mathrm{~L}^{-1}\right)$ for the first and second time at day $\mathrm{i}, \mathrm{V}_{1 \mathrm{i}}$ and $\mathrm{V}_{2 \mathrm{i}}$ are the consumption volume of $\mathrm{H}_{2} \mathrm{SO}_{4}(\mathrm{~mL})$ for the first and second time at day $\mathrm{i}$, $\mathrm{t}$ is the duration of each collection (h), and $\mathrm{R}$ is the cross-sectional area of the chamber $(\mathrm{m})$.

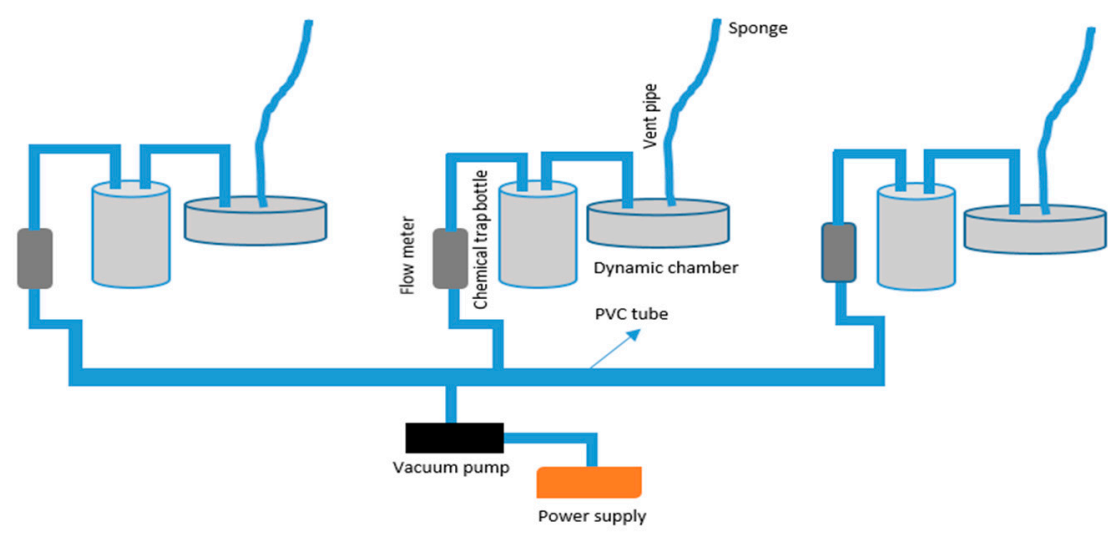

Figure 1. Schematic diagram of $\mathrm{NH}_{3}$ gas collection sampling set up.

\subsection{Soil Samples and Plant Collection}

During the collection of ammonia volatilization, the fresh soil samples were collected and stored frozen. The $50 \mathrm{~g}$ of surface soil samples were collected three times randomly near the ammonia volatilization sampling point in each plot. The water content of the collected fresh soil samples was measured, as well as the extracted $\mathrm{NH}_{4}{ }^{+}-\mathrm{N}$. Fresh soil samples were sieved with a $2 \mathrm{~mm}$ sieve. After that, $10 \mathrm{~g}$ of the soil sample was put into a $100 \mathrm{~mL}$ plastic bottle. Then $50 \mathrm{~mL}$ of $0.01 \mathrm{~mol} \mathrm{~L}^{-1} \mathrm{CaCl}_{2}$ solution was added and shaken for $1 \mathrm{~h}$. The extractable soil $\mathrm{NH}_{4}{ }^{+}$was measured using an auto-analyzer 3(AA3) $[35,36]$. The rest of the soil samples were air-dried at room temperature to measure soil $\mathrm{pH}$. The $\mathrm{pH}$ value of the soil was determined using distilled water suspensions. The soil to solution ratio was 1 to 2.5 (w:v). After shaking the suspensions for five minutes at $300 \mathrm{rpm}$ on an orbital shaker, the samples were kept for $30 \mathrm{~min}$ at room temperature for sedimentation. The $\mathrm{pH}$ was then measured in the liquid supernatant [37]. During the harvesting of summer maize-winter wheat season, three 
separate areas (each $4 \mathrm{~m}^{2}$ ) were selected in the center of each plot and they were harvested to determine the fresh yield. After that, fresh yield was dried at natural sunlight and measured the actual yield of maize and wheat.

\subsection{Environmental Indicator}

A small weather station was set near the field to monitor the environmental indicators, such as air temperature, ground temperature, and wind speed. A rain gauge near our field was used to measure precipitation.

\subsection{Statistical Analysis}

Statistical analyses of the data were performed using the SPSS 22.0 analytical software package. A one-way ANOVA was carried out to test whether the differences in soil properties and $\mathrm{NH}_{3}$ gas fluxes among all the treatments were significant at the Turkey HSD test 0.05 probability level. Microsoft Excel Professional Plus 2016 was used for graphic design.

\section{Results}

\subsection{Environment Parameters}

The precipitation was $373 \mathrm{~mm}$ in the maize season, and $75 \%$ of rainfall occurred between July and August in the maize season (Figure 2). The total amount of precipitation was very low $(69 \mathrm{~mm})$ in wheat season, of which $75 \%$ happened in April. The daily air temperature ranged from $12.9^{\circ} \mathrm{C}$ to $31.6^{\circ} \mathrm{C}$ and $-9.1^{\circ} \mathrm{C}$ to $28.7{ }^{\circ} \mathrm{C}$ with a mean of $25^{\circ} \mathrm{C}$ and $7.4^{\circ} \mathrm{C}$ in maize and wheat seasons, respectively (Figure 1). The trend of daily ground soil temperature was consistent with the air temperature. The daily ground soil temperature ranged from $13.9^{\circ} \mathrm{C}$ to $39.4{ }^{\circ} \mathrm{C}$ with a mean $13.9{ }^{\circ} \mathrm{C}$ in maize season and $-7.2^{\circ} \mathrm{C}$ to $36^{\circ} \mathrm{C}$ with a mean $10{ }^{\circ} \mathrm{C}$ in wheat season (Figure 2).
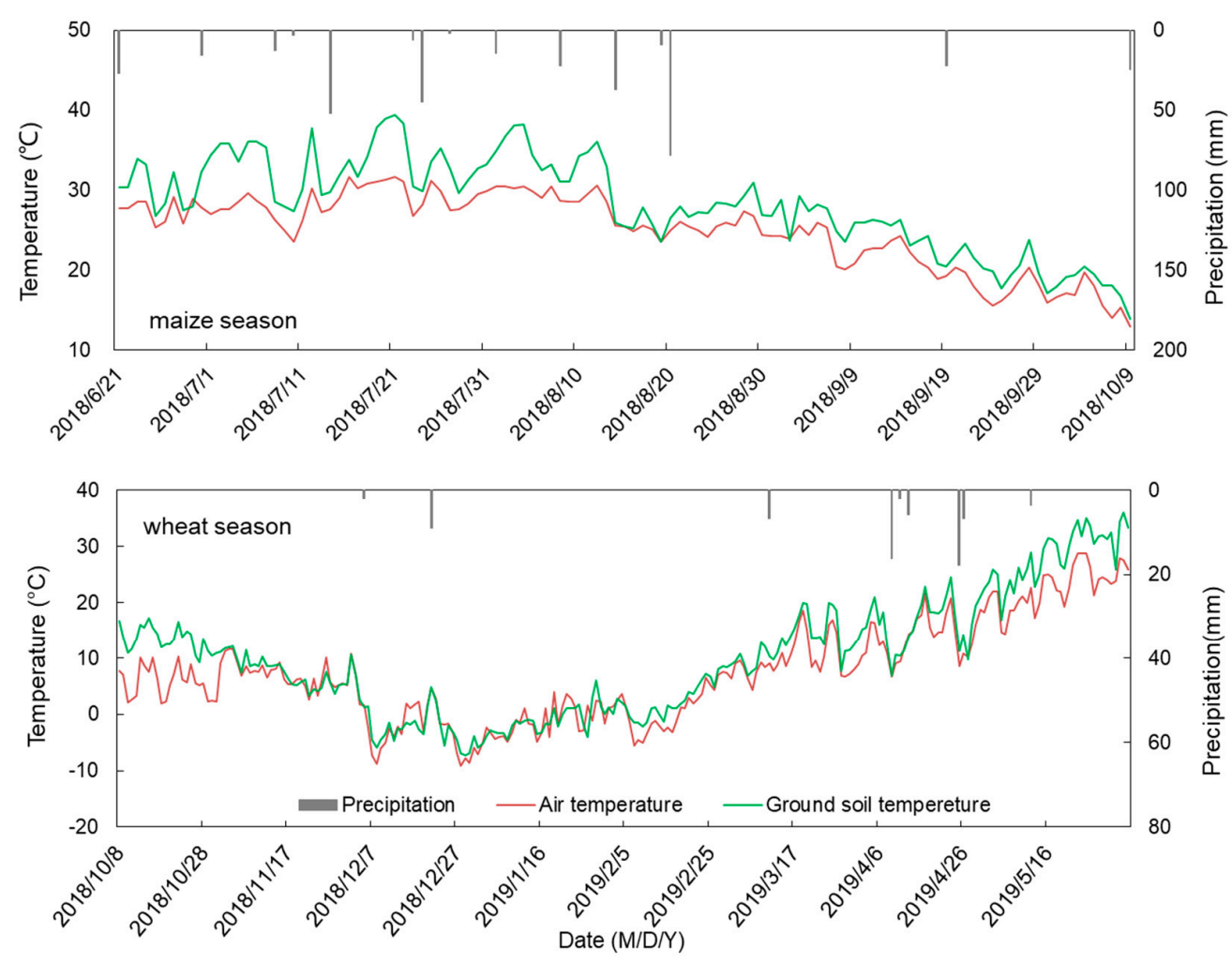

Figure 2. Daily air temperature, ground soil temperature, and precipitation across the 2018/2019 wheat and maize season. 
Temporal trends of soil $\mathrm{NH}_{4}{ }^{+}-\mathrm{N}$ concentration showed a similar pattern for all the $\mathrm{N}$ treatments. The soil $\mathrm{NH}_{4}{ }^{+}-\mathrm{N}$ concentration was significantly affected by $\mathrm{N}$ application, water irrigation and rainfall events, BS input, and air temperature in both maize and wheat season (Figure 3). A high peak value occurred on the second and fourth day after the basal and tillering fertilization application and it then sharply decreased. The maximum concentration, $1.66 \mathrm{mg} / \mathrm{kg}$, appeared on second day after basal fertilizer in treatment CK and it was four times higher than the average concentration, in maize season. The maximum concentration, $3.87 \mathrm{mg} / \mathrm{kg}$, appeared on first day after the basal fertilizer in treatment $\mathrm{CK}$ and it was 1.5 times higher than the average concentration, in wheat season. It is clear that CK produced the highest $\mathrm{NH}_{4}{ }^{+}-\mathrm{N}$ concentration compared to the other treatments. During the wheat season, among all treatments, $\mathrm{CK}$ produced the highest $\mathrm{NH}_{4}{ }^{+}-\mathrm{N}$ concentration after basal, water, and biogas slurry irrigation.
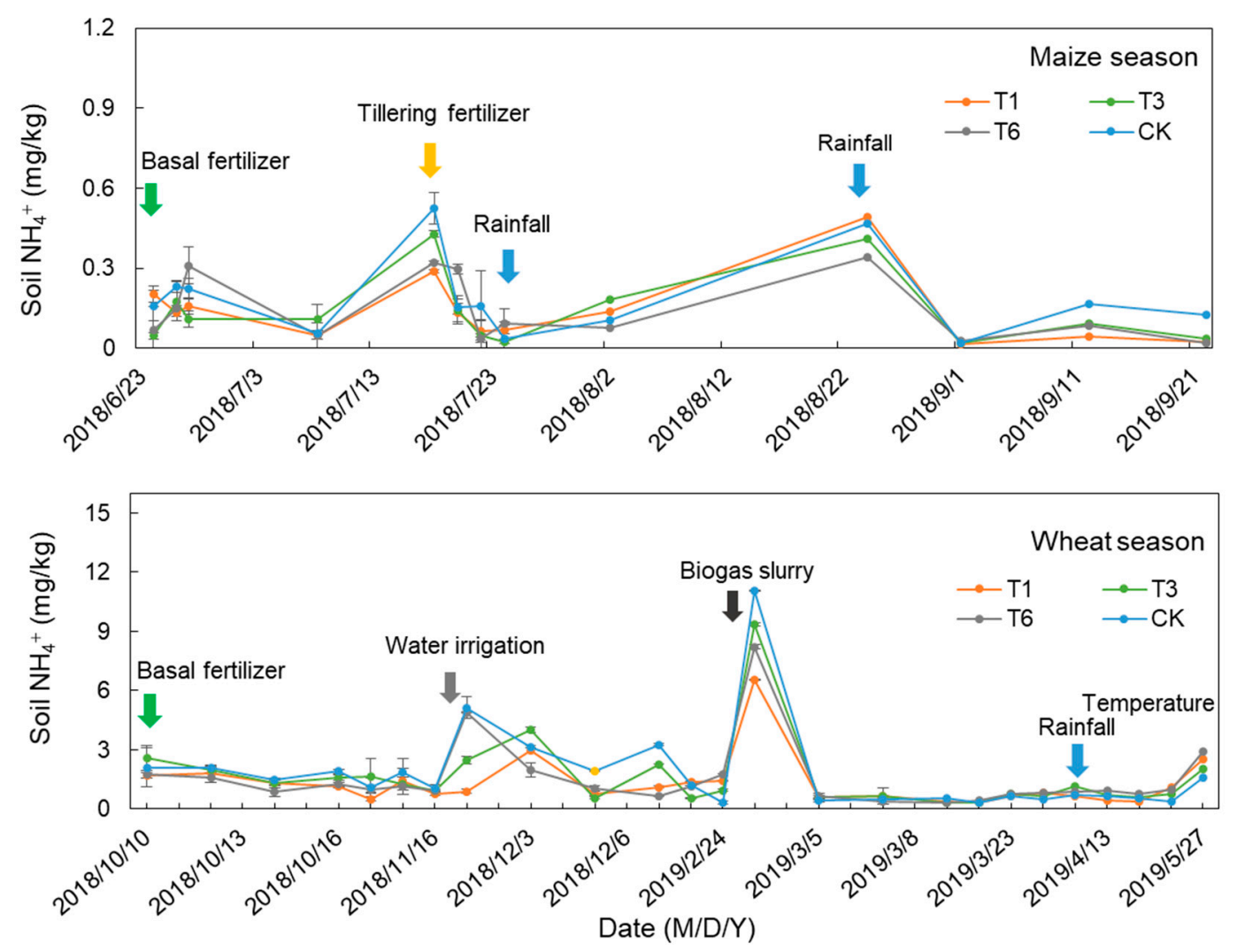

Figure 3. Seasonal variations in ammonium $\mathrm{N}$ concentrations in soil of different treatments during the 2018/2019 wheat and maize season. The vertical bars mean standard errors. Different color of down arrow indicates different event during both maize and wheat season. Maize season: $226.5 \mathrm{~kg} \mathrm{~N} \mathrm{ha}^{-1}$ of CF applied in every treatment. Wheat season: $68 \mathrm{~kg} \mathrm{~N}$ ha $^{-1}$ of chemical fertilizer applied in base fertilizer stage. Tillering stage, T1: 0 CF + 158 BS, T3: 79 CF + 79 BS, T6: 126 CF + 32 BS, CK: 158 CF + 0 $\mathrm{BS}$, where $\mathrm{CF}=$ Chemical fertilizer, $\mathrm{BS}=$ Biogas slurry, different number indicates different amount of nitrogen per hectare.

The $\mathrm{pH}$ value ranges between 7.60 to 8.12 in the maize season and 7.41 to 8.25 in the wheat season (Figure 4), but there was no significant difference among the treatments. 

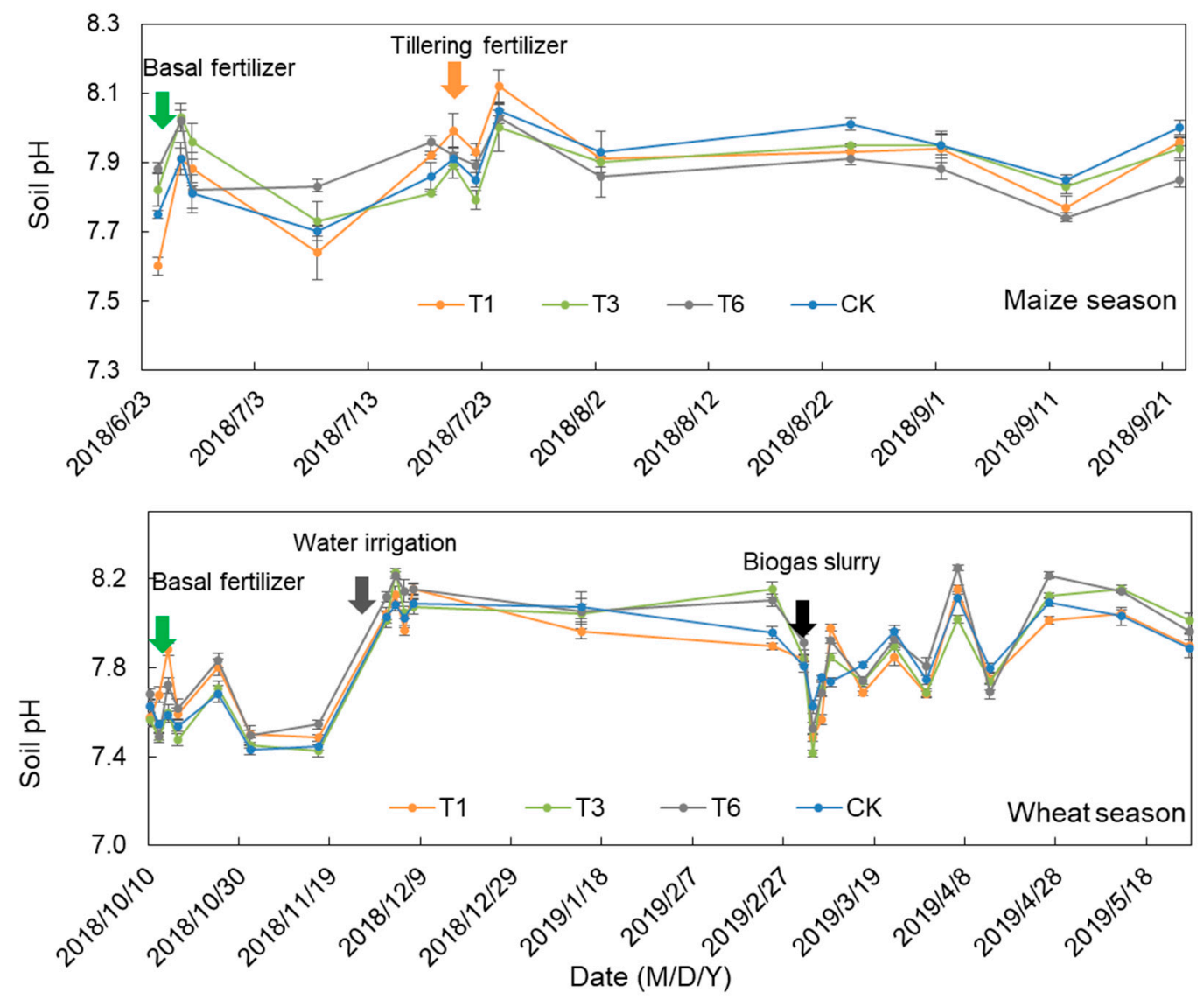

Figure 4. Seasonal variations of the soil pH after the N application events and during the 2018/2019 maize and wheat season. The vertical bars mean standard errors. Different colors of down arrow indicate different events during both maize and wheat season. Maize season: $226.5 \mathrm{~kg} \mathrm{~N} \mathrm{ha}^{-1}$ of CF applied in every treatment. Wheat season: $69 \mathrm{~kg} \mathrm{~N} \mathrm{ha}^{-1}$ of chemical fertilizer applied in base fertilizer stage. Tillering stage, T1: $0 \mathrm{CF}+158 \mathrm{BS}, \mathrm{T} 3: 79 \mathrm{CF}+79 \mathrm{BS}, \mathrm{T} 6: 126 \mathrm{CF}+32 \mathrm{BS}, \mathrm{CK}: 158 \mathrm{CF}+0 \mathrm{BS}$, where $\mathrm{CF}=$ Chemical fertilizer, $\mathrm{BS}=$ Biogas slurry, different number indicates different amounts of nitrogen per hectare.

\subsection{Flux of Ammonia Volatilization in Whole Season}

During the maize season, all treatment showed a trend of increasing AV after fertilization followed by a trend of decrease (Figure 5). On the third day, all four treatments were in peak position and then decreased gradually to flat until the tillering fertilizer application. Although the highest accumulation appeared in CK treatment, there was no was significant difference among the treatments. Maximum emissions happened after tillering fertilizer but very little after basal fertilizer. After basal fertilization, the cumulative ammonia volatilization of about $2.40 \pm 0.42,1.70 \pm 0.05,1.09 \pm 0.03$, and $1.85 \pm 0.05$, $(\mathrm{kg} / \mathrm{ha} / \mathrm{d})$ was found in CK, T1, T3, and T6 treatments, respectively, and the overall performance was CK $>\mathrm{T} 6>\mathrm{T} 1>\mathrm{T} 3$ (Table 4). The AV rate peaked on the second day, continued in the next four days after tillering fertilizer, and then, gradually decreased until 24 July. On the second day, the highest value in CK was $14.10 \mathrm{~kg} / \mathrm{ha} / \mathrm{d}$ and the lowest value in T1 was $8.58 \mathrm{~kg} / \mathrm{ha} /$ day. After tillering fertilization, the cumulative AVs were $26.19 \pm 0.10,14.34 \pm 0.66,22.87 \pm 0.98$, and $21.13 \pm 0.90,(\mathrm{~kg} / \mathrm{ha} / \mathrm{d}$ in CK, T1, T3, and T6 treatments, respectively. There was no significant result found after tillering fertilizer, although significant results were observed in separate events on 20 July, 22, and 24 July. Total AV after tillering fertilizer showed this trend: CK > T3 > T6 > T1 (Table 4).

During the whole growing season of maize, the highest accumulation was shown in CK about $28.9 \mathrm{~kg} / \mathrm{ha} / \mathrm{d}$ and T1, T3, and T6 about $14.34 \mathrm{~kg} / \mathrm{ha} / \mathrm{d}, 22.87 \mathrm{~kg} / \mathrm{ha} / \mathrm{d}$, and $21.13 \mathrm{~kg} / \mathrm{ha} / \mathrm{d}$, respectively. 


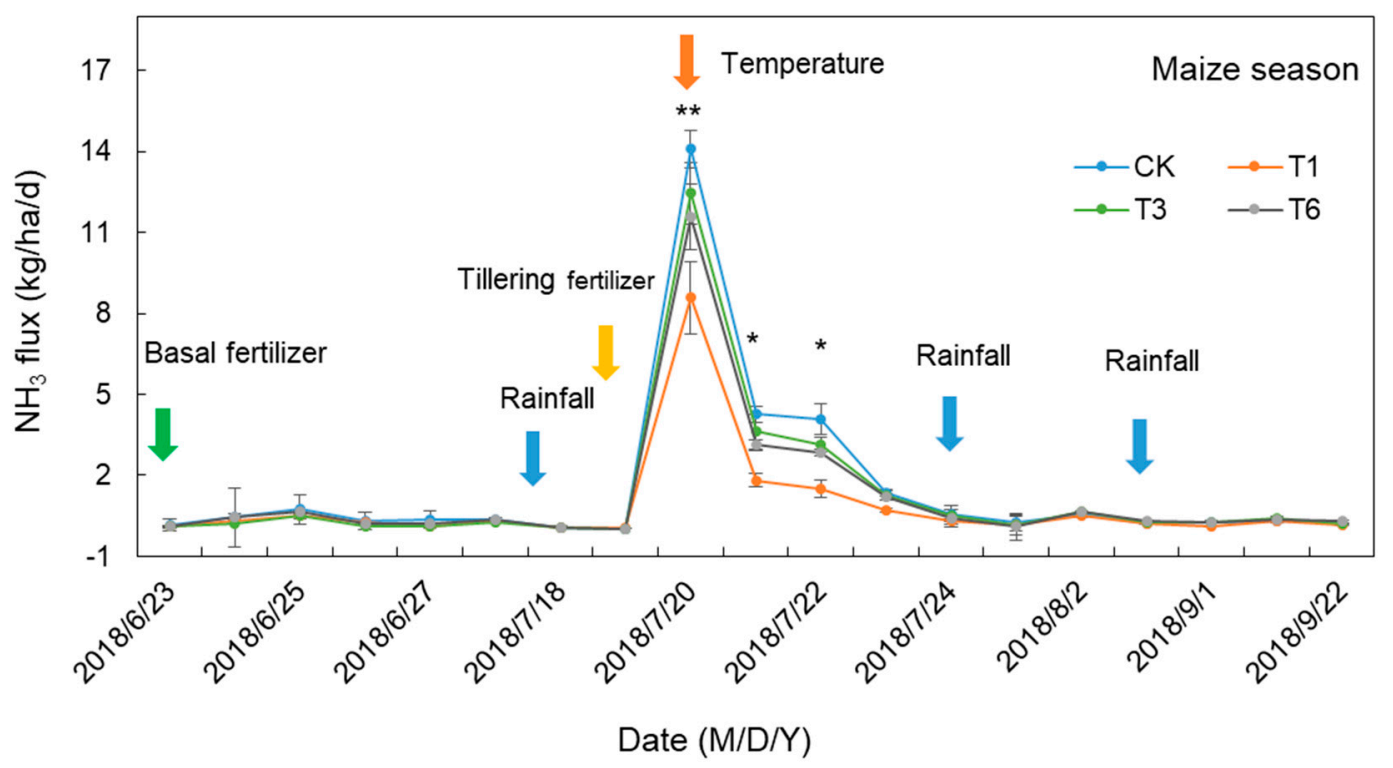

Figure 5. Trend of daily NH3-N emissions following the basal and the tillering fertilization during maize season. Single star $\left(^{*}\right)$ and double star $\left(^{* *}\right)$ represents the significant daily difference, $p<0.05$ and $p<0.01$ respectively. Statistical difference according to the Turkey HSD test at probability level $p<0.05$. The vertical bars mean standard errors. Different colors of down arrow indicate different events during maize season. Total $226.5 \mathrm{~kg} \mathrm{~N} \mathrm{ha}^{-1}$ of CF applied in every treatment.

Table 4. Amount of ammonia volatilization for each fertilization and the whole period for the four different treatments in maize and wheat season.

\begin{tabular}{cccccc}
\hline \multirow{2}{*}{ Varieties } & \multirow{2}{*}{ Fertilizer Type } & \multicolumn{4}{c}{ Treatments } \\
\cline { 2 - 5 } & & T1 & T3 & T6 & CK \\
\hline \multirow{3}{*}{ Maize } & Basal fertilization & $1.70 \pm 0.05 \mathrm{~b}$ & $1.09 \pm 0.03 \mathrm{~b}$ & $1.85 \pm 0.05 \mathrm{~b}$ & $2.40 \pm 0.42 \mathrm{a}$ \\
\cline { 2 - 5 } & Tillering fertilization & $14.34 \pm 0.66 \mathrm{a}$ & $22.87 \pm 0.98 \mathrm{a}$ & $21.13 \pm 0.90 \mathrm{a}$ & $26.19 \pm 0.10 \mathrm{a}$ \\
\cline { 2 - 5 } & Whole season & $16.04 \pm 0.43 \mathrm{a}$ & $23.96 \pm 0.65 \mathrm{a}$ & $22.98 \pm 0.59 \mathrm{a}$ & $28.59 \pm 0.72 \mathrm{a}$ \\
\hline \multirow{3}{*}{ Wheat } & Basal fertilization & $5.88 \pm 0.05 \mathrm{~b}$ & $5.96 \pm 0.05 \mathrm{~b}$ & $6.50 \pm 0.06 \mathrm{~b}$ & $7.79 \pm 0.08 \mathrm{a}$ \\
\cline { 2 - 5 } & Tillering fertilization & $5.00 \pm 0.04 \mathrm{~b}$ & $7.14 \pm 0.07 \mathrm{ab}$ & $6.58 \pm 0.05 \mathrm{ab}$ & $8.29 \pm 0.10 \mathrm{a}$ \\
\cline { 2 - 5 } & Whole season & $10.87 \pm 0.04 \mathrm{~b}$ & $13.10 \pm 0.04 \mathrm{~b}$ & $13.08 \pm 0.04 \mathrm{~b}$ & $16.08 \pm 0.06 \mathrm{a}$ \\
\hline
\end{tabular}

Note: Standard Errors are shown in every treatment. Statistical difference was analyzed according to the Turkey HSD test at probability level $p<0.05$. Small letters indicate the significant differences between treatments according to the post hoc Duncan test.

After applying the base fertilizer, all treatments had a significant effect on AV, which showed a trend of increasing at first and then decreasing in the wheat season (Figure 6). AV mainly occurred within seven days after fertilization. On the third day, all four treatments were in peak position after basal fertilization and then decreased gradually and became flat except a small peak was observed on 1 November. Another peak point was found on 5 December after water irrigation. The highest peak was found in CK treatment at $0.873 \mathrm{~kg} / \mathrm{ha} / \mathrm{d}$. At the end of basal fertilization, in January and February, we recorded higher value in CK treatment compared to the other three treatments. After basal fertilization, the cumulative AVs of $7.79 \pm 0.08,5.88 \pm 0.05,5.96 \pm 0.05$, and $6.50 \pm 0.06,(\mathrm{~kg} / \mathrm{ha} / \mathrm{d})$ were found in CK, T1, T3, and T6 treatments, respectively, and the overall performance was CK > T6 > T3 > T1 (Table 4). The highest accumulation appeared in CK treatment and it is significantly different in comparison to the other treatments. Similar trends were observed after tillering fertilization. The AV rate peaked on the second to third day after fertilization. On the third day, the highest value in CK was $1.641 \mathrm{~kg} / \mathrm{ha} / \mathrm{d}$ and the lowest value in T1 was $0.559 \mathrm{~kg} / \mathrm{ha} / \mathrm{d}$. After tillering fertilization, the cumulative AVs of $8.29 \pm$ 
$0.10,5.00 \pm 0.04,7.14 \pm 0.07$, and $6.58 \pm 0.05,(\mathrm{~kg} / \mathrm{ha} / \mathrm{d})$ were found in $\mathrm{CK}, \mathrm{T} 1, \mathrm{~T} 3$, and $\mathrm{T} 6$ treatments, respectively, and the overall performance was $\mathrm{CK}>\mathrm{T} 3>\mathrm{T} 6>\mathrm{T} 1$ (Table 2). The highest accumulation appeared in CK treatment and it is only significantly different compared to the T1 treatment.

During the whole growing season of wheat, the highest accumulation was shown in CK at $16.08 \mathrm{~kg} / \mathrm{ha} / \mathrm{d}$. The cumulative AV for wheat season showed a trend: CK $>\mathrm{T} 3>\mathrm{T} 6>\mathrm{T} 1$ (Table 4).

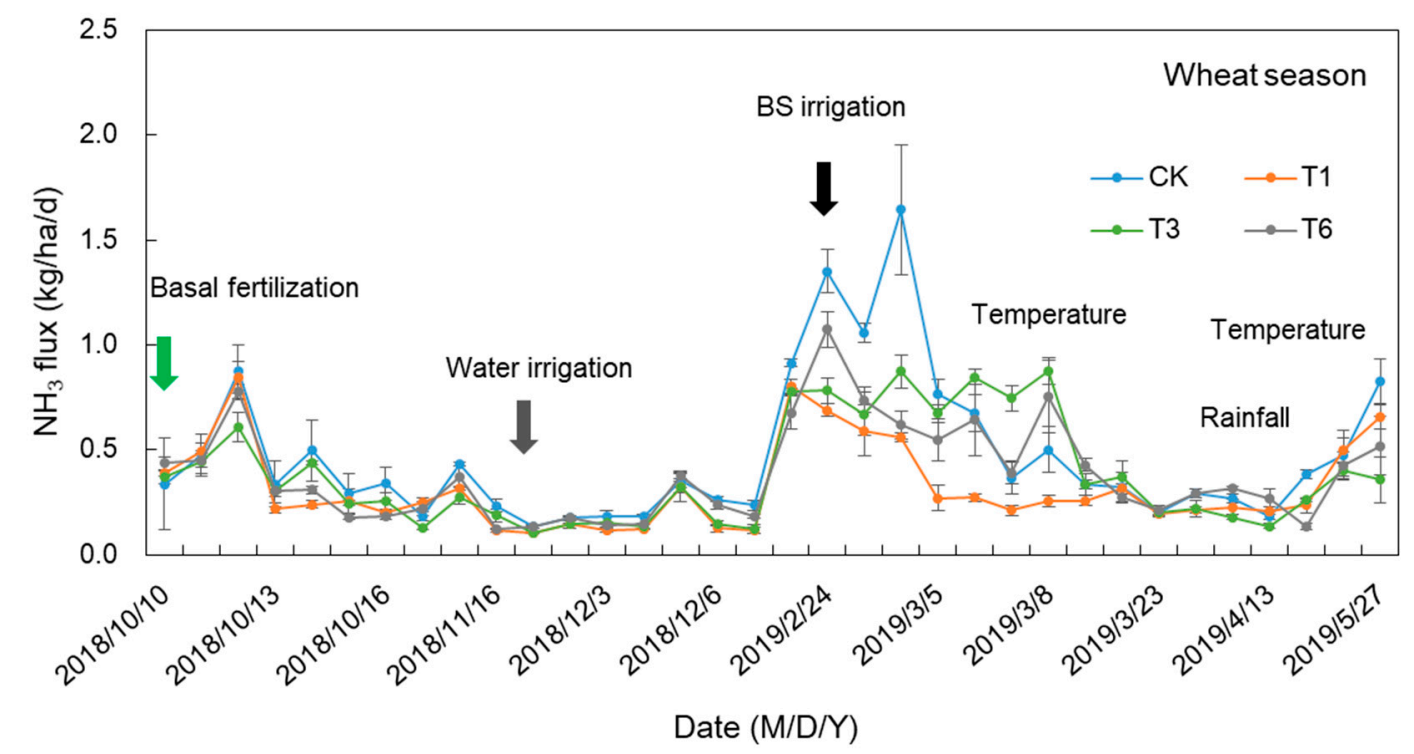

Figure 6. Trend of daily $\mathrm{NH}_{3}-\mathrm{N}$ emissions following the Basal and the tillering fertilization and water irrigation. The vertical bars mean standard errors. Different color of down arrow indicates different event during wheat season. Wheat season: $68 \mathrm{~kg} \mathrm{~N} \mathrm{ha}^{-1}$ of chemical fertilizer applied in base fertilizer stage. Tillering stage, T1: 0 CF + 158 BS, T3: 79 CF + 79 BS, T6: 126 CF + 32 BS, CK: 158 CF + 0 BS, where $\mathrm{CF}=$ Chemical fertilizer, $\mathrm{BS}=$ Biogas slurry, different number indicates different amount of nitrogen per hectare.

\subsection{Optimal Ratio of BS Substitution}

In maize season, the grain yield from the four different treatments averaged $5.62 \mathrm{tha}^{-1}$ in a range of 4.63-6.96 tha ${ }^{-1}$. Treatment T3 produced the highest yield of $6.96 \mathrm{tha}^{-1}$, where T1, T6, and CK produced $4.63,5.00$, and $5.88 \mathrm{t} \mathrm{ha}^{-1}$, respectively (Table 5). There was no significant difference found among the treatments. In wheat season, the grain yield averaged $5 \mathrm{t} \mathrm{ha}^{-1}$ with a range of 3.33-6.25 $\mathrm{t} \mathrm{ha}^{-1}$ (Table 5). Treatment CK produced the highest yield of $6.25 \mathrm{tha}^{-1}$, where T1, T3, and T6 produced $3.33,4.87$, and $5.57 \mathrm{tha}^{-1}$, respectively. $\mathrm{T} 1$ is significantly lower than other treatments.

Table 5. Grain yield in both maize and wheat season of the four different treatments.

\begin{tabular}{ccccc}
\hline \multirow{2}{*}{ Varieties } & \multicolumn{4}{c}{ Grain Yield, kg/ha } \\
\cline { 2 - 5 } & T1 & T3 & T6 & CK \\
& $(\mathbf{1 5 8}$ BS + 0 CF) & $\mathbf{( 1 2 6 ~ B S ~ + ~ 3 2 ~ C F ) ~}$ & (79 BS + 79 CF) & (0 BS + 158 CF) \\
\hline Maize & $4625 \pm 257 \mathrm{a}$ & $6958 \pm 1214 \mathrm{a}$ & $5875 \pm 358 \mathrm{a}$ & $5000 \pm 118 \mathrm{a}$ \\
\hline Wheat & $3329 \pm 146 \mathrm{~b}$ & $4868 \pm 233 \mathrm{a}$ & $5562 \pm 29 \mathrm{a}$ & $6250 \pm 270 \mathrm{a}$ \\
\hline
\end{tabular}

Note: The different lowercase letters in the same row indicate significant differences and same lowercase letters in the same row indicate no significant differences among the treatments according to Tukey HSD test $(p<0.05$; $n=3$ ), where BS = biogas slurry, and CF = Chemical fertilizer. Biogas slurry only applied in wheat season and only chemical fertilizer applied in maize season. Different numbers indicate different amounts of nitrogen per hectare. 
During the maize season, we used only CF, while in the wheat season, we substituted part of the chemical fertilizer by biogas slurry. Different ratios of biogas slurry, such as $100 \%, 80 \%$, and $50 \%$, combined with chemical fertilizer were used (Figure 7). From the figure, it is clear that CK produced maximum yield of all. The yield decreased following the increasing ratio of BS. To simulate the optimal ratio of BS substitution, we firstly fitted a curve (Figure 6) to find out that the ratio of $38 \%$ BS with $62 \% \mathrm{CF}$ would give the equivalent yield with CK. And then, we verified under the ratio of $38 \% \mathrm{BS}$ substitution, $\mathrm{NH}_{3}$ flux was $13.92 \mathrm{~kg} / \mathrm{ha}$, which was $13.5 \%$ lower than $\mathrm{NH}_{3}$ flux of $\mathrm{CK}$. The optimal ratio of BS substitution was $38 \%$ based on this simulation (Figure 7 ).
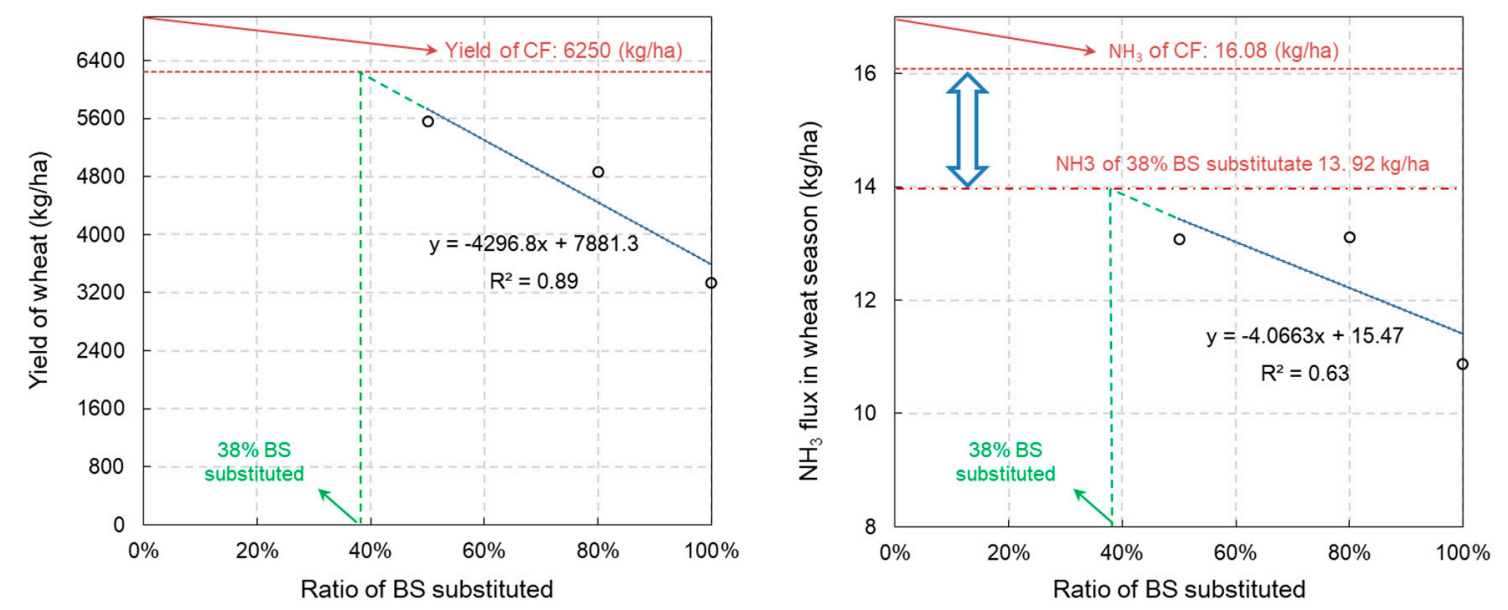

Figure 7. Yield of wheat versus ratio of biogas slurry (BS) substitution and $\mathrm{NH}_{3}$ emission versus ratio of biogas slurry (BS) substitution. CF means chemical fertilizer.

\section{Discussion}

\subsection{Factors That Control the AV}

$\mathrm{AV}$ was found to be the main way of nitrogen loss in the field, and the amount of loss was closely related to fertilization type and nitrogen application rate [38-41]. $\mathrm{NH}_{3}$ emission contributed to $19.4 \pm 5.2 \%$ and $24.7 \pm 5.6 \%$ of total $\mathrm{N}$ application rate in wheat and maize season, respectively, in NCP and typical $\mathrm{pH}$ of calcareous soil is 7.5 to $8.5 \mathrm{in} \mathrm{NCP}$, where urea or ammonium bicarbonate are used, accounting for $80 \%$ of total fertilizers. Therefore, $\mathrm{AV}$ is usually considered the main $\mathrm{N}$ loss pathway in the maize season on NCP [3].

The factors that control the $\mathrm{NH}_{3}$ flux were soil $\mathrm{NH}_{4}{ }^{+}$, water input (irrigation and precipitation), soil $\mathrm{pH}$, air temperature, and wind speed [42-45]. After being applied to the soil, urea hydrolyzes firstly. The hydrolysis rate of urea is correlated with the availability of water, urease activity, $\mathrm{pH}$, and air temperature [46-48]. Water input is important for urea hydrolysis, which is related to soil microbial and enzymatic activity $[49,50]$. Hydrolysis of urea will be delayed or inhibited if the soils are very dry and water content lower than the permanent wilting point. Normally, the rate of hydrolysis will increase if the water content of the soil increases [47,48].

In this study, we observed an increase of $\mathrm{NH}_{3}$ emission after water irrigation in the wheat season [51] also proved that $\mathrm{AV}$ rate from soil irrigated immediately following fertilizer application is considerably higher than that from soil irrigated $5 \mathrm{~h}$ after fertilization. However, too much water input has the potential to carry urea or BS into the soil, minimizing loss of volatilization $[7,38,45]$. Previous studies found that rainfall increased infiltration of $\mathrm{NH}_{4}{ }^{+}$into the soil, contributing to a reduction in AV. In this study, after rainfall on 23 and 24 July, $\mathrm{AV}$ decreased due to the loss of $\mathrm{NH}_{4}{ }^{+}$concentration. In soils where water content is higher, activity of urease increases with temperature [48]. Optimum $\mathrm{pH}$ for soil urease activity ranges between $\mathrm{pH} 8$ and 9 . Hydrolysis of urea can be delayed in low $\mathrm{pH}$ soils or after adding acidifying anions combined with urea [52]. 
Urea in solution is hydrolyzed to $\mathrm{NH}_{4}$ ions and dissolved to $\mathrm{NH}_{3}$ (aq). An equilibrium exists between these two forms, that is governed by the $\mathrm{pH}$ and air temperature. Based on the acid base equilibrium, we found that the $\mathrm{NH}_{3}$ loss is low if $\mathrm{pH}<7$, but it increases noticeably when $\mathrm{pH}$ is $>$ 7 [47]. Other than the formation of $\mathrm{NH}_{3}(\mathrm{aq})$, air temperature controls equilibrium distribution between the $\mathrm{NH}_{3}(\mathrm{~g})$ and $\mathrm{NH}_{3}(\mathrm{aq})$. On-site observations proved that high air temperature, which promoted the formation of $\mathrm{NH}_{3}(\mathrm{aq})$ and accompanying $\mathrm{NH}_{3}(\mathrm{~g})$, significantly increased $\mathrm{NH}_{3}$ emission [11,53]. In this study, we saw a raise of $\mathrm{NH}_{3}$ fluxes after 1 May 2019 because the air temperature was higher than $20^{\circ} \mathrm{C}$. The roughness of surface soil contributed to the increase in turbulence, which resulted in an improvement in the friction speed. Consequently, it increases the exchange between the atmosphere and the surface of soil. Therefore, the top portion of $\mathrm{NH}_{3}$ gas mixed perfectly and circulated in the atmosphere and increased the $\mathrm{NH}_{3}$ emission. Accordingly, it increased the $\mathrm{NH}_{3}$ emission from supplied fertilizers due to the increasing temperature and wind speed. In contrast, high ground radiation, along with increasing wind speed, will decrease ground and plant surrounding temperatures and, subsequently, the possible emission from the solution. Hence, several studies of AV from applied manure to farmland revealed that $\mathrm{NH}_{3}$ emissions were not always associated with wind speed [42,47].

CF substituted by BS significantly reduced ammonia volatilization loss than urea in this study. Similar results were proved by previous studies in northern China for the wheat yield cropping system [51,54]. Urea is an alkaline fertilizer, it will hydrolyze and produce $\mathrm{NH}_{4}{ }^{+}$and $\mathrm{OH}^{-}$rate of hydrolysis depending on soil $\mathrm{pH}$ and temperature [47]. BS also contains a higher amount of $\mathrm{NH}_{4}{ }^{+}-\mathrm{N}$ concentrations and has higher slurry surface $\mathrm{pH}$, which significantly affects ammonia emission [44]. However, through the same amount of $\mathrm{N}$ input, applications of different $\mathrm{CF}$ and $\mathrm{BS}$ ratio led to different soil $\mathrm{NH}_{4}{ }^{+}, \mathrm{pH}$. We can see higher soil $\mathrm{NH}_{4}{ }^{+}$and $\mathrm{pH}$ for $\mathrm{CK}$ treatment after tillering fertilization both in maize and wheat seasons (Figures 5 and 6). That is the reason why $\mathrm{NH}_{3}$ flux for $\mathrm{BS}$ treatment were lower than CK.

\subsection{Effects of Fertilizer Type on Crop Yield}

The farmers use CF to increase crop production. However, if only CFs are continuously applied, it causes soil acidification and compaction, reduced fertility, and severe decline of land productivity, which seriously threatens the production capacity of farmland and its self-repairing capability and endangers the sustainable agricultural growth $[41,55]$. As we know, BS is considered a good source of macro $(\mathrm{N}, \mathrm{P}, \mathrm{K})$ and micronutrients $(\mathrm{Zn}, \mathrm{Mn}, \mathrm{B})$ that are necessary for plant growth [41]. However, if only organic manure is added to the soil, the desired increase in crop yield cannot be achieved according to our results and the previous study [30].

Crop productivity can be significantly increased if the slurry is used in combination with $\mathrm{CF}[31,32]$. Likewise, BS and CF combination increased peanut grain yield and biomass, due to the increase of soil $\mathrm{N}$ availability. A similar effect was observed in rice, where a 10\% yield increase occurred with a BS-CF combination. Moreover, the combination of BS-CF improved the yields in rapeseed [56]. In line with recent studies, medium concentration of BS to replace CFs herein significantly increased the crop yields, and NUE in NCP [57]. Similarly, a moderate ratio of manure $(<40 \%)$ substituted by CF could reduce $\mathrm{NH}_{3}$ emissions and increase crop yields significantly were proved [5]. In this study, 38\% of BS for substitution was proposed, which is not similar to previous studies. Previous studies only discussed BS and CF used separately. However, in our study, we used combined BS-CF and developed the ratio of $38-62 \%$, which is a completely new idea.

\subsection{Effects of Substituting Chemical Fertilizer by Biogas Slurry}

CF substituted by BS significantly reduced ammonia emission in this study. Full substitution of $\mathrm{CF}$ by manure significantly decreased the AV in upland crops and rice fields [58]. However, full substitution of $\mathrm{CF}$ led to a yield penalty in both types of crops. Recent studies have suggested that a moderate ratio $(<40 \%)$ of CF substitute by manure significantly increased NUE by $14.0 \%$ and $25.1 \%$ for upland crops and rice, respectively [5]. Studies also found that medium concentration of digestate 
biogas slurry (MDBS) increased the yield both in wheat and maize season. After that, no significant growth in yield was observed with a further increase in higher concentration of digestate biogas slurry (HDBS). The average nitrate leaching losses were $6 \%$ and $5 \%$ produced by CF and MDBS, respectively, in wheat growing season. In maize growing season, the average leaching losses were $10 \%$ and $8 \%$ contributed by CF and MDBS, respectively. In both growing season, CF produced the highest leaching loss compare to MDBS. Whereas higher concentration of digestate biogas slurry (HDBS) increased the leaching loss in comparison to MDBS. Therefore, MDBS increased the NUE with decreased leaching loss [57]. From the above two articles, it was clear that a moderate ratio of BS or partial substitution of CF by manure increased crop yield, NUE, and concurrently decreased AV and as well as N leaching. Similar results were observed in our study. We found that full substitution of CF by BS significantly decreased the AV in comparison to CF. However, full substitution of CF by BS led to a yield penalty. Different ratios of BS, such as $100 \%, 80 \%$, and $50 \%$, combined with $\mathrm{CF}$, were used in our study. The yield was decreased following the increasing ratio of BS. From the above discussion, we come to this point that a moderate ratio of CF substituted by either BS or manure could increase the crop yield and synchronously reduced AV. Our findings, CF substituted by a ratio of $38 \% \mathrm{BS}$, significantly decreased the $\mathrm{AV}$ and increased the crop yield.

\section{Conclusions}

The main ambition of this study was to systematically evaluate and forecast $\mathrm{NH}_{3}$ losses during maize and wheat season after biogas slurry was applied in the field, compared with the CF practice at NCP. For both crops, the highest AV was obtained by CK treatment. Different emissions were found in maize season, although the amount of fertilization was the same and only CF was applied at that time. A possible reason for this may be the effect of BS from last year. In wheat season, the highest yield, as well as ammonia emission, was produced by $\mathrm{CF}$ and this yield could be produced from the ratio of $38 \%$ BS mixed with $62 \%$ CF. The ratio of $38 \%$ BS substitution, $\mathrm{NH}_{3}$ flux was $13.92 \mathrm{~kg} / \mathrm{ha}$, which was $13.5 \%$ lower than $\mathrm{NH}_{3}$ flux of $\mathrm{CK}$. The novelty of this research was the lowest emissions and highest crop yield were observed in the combined use of both BS-CF and the ratio of 38:62. We conclude that there are great potentials for substituting CF by BS, and the optimal ratio of $38 \%$ BS was suggested to produce the highest yield and lowest $\mathrm{NH}_{3}$ emissions. Further research is required to find the optimum ratio of $\mathrm{CF}$ combine with $\mathrm{BS}$ could be an alternative agricultural strategy to obtain desired crop yield and simultaneously reduce the AV.

Author Contributions: Conceptualization, M.A.R., X.Z. and Q.Z.; methodology, M.A.R., X.Z. and Q.Z.; software, M.A.R. and X.Z.; validation, Q.Z., M.A.R., and X.Z.; formal analysis, M.A.R., X.Z. and Q.Z.; investigation, M.A.R., X.Z., S.L. (Shuqin Li), S.L. (Shengmei Lv), Y.L. and H.Z.; resources, Q.Z.; data curation, M.A.R., X.Z., S.L. (Shuqin Li), S.L. (Shengmei Lv), Y.L. and H.Z.; writing—original draft preparation, M.A.R., X.Z. and Q.Z.; writing-review and editing, M.A.R., X.Z. and Q.Z.; visualization, M.A.R. and X.Z.; supervision, Q.Z.; project administration, Q.Z.; funding acquisition, Q.Z., X.Z., S.L. (Shuqin Li). All authors have read and agreed to the published version of the manuscript.

Funding: Financial support for this paper was provided by the National Natural Science Foundation of China (41977072, 41907087), Central Public-interest Scientific Institution Basal Research Fund (BSRF201905), and Innovation Training Project for College Students: Nitrogen loss pathway and driven factors of wheat-maize rotation system in north China plain under the condition of biogas slurry application (2020).

Acknowledgments: We appreciate the institutional funding by the Institute of Environment and Sustainable Development in Agriculture, Graduate School of Chinese Academy of Agricultural Sciences, Beijing, China, making this research possible.

Conflicts of Interest: The authors declare no conflict of interest.

\section{References}

1. Carlson, K.M.; Gerber, J.S.; Mueller, N.D.; Herrero, M.; MacDonald, G.K.; Brauman, K.A.; Havlik, P.; O'Connell, C.S.; Johnson, J.A.; Saatchi, S.; et al. Greenhouse gas emissions intensity of global croplands. Nat. Clim. Chang. 2016, 7, 63-68. [CrossRef] 
2. Zhao, R.F.; Chen, X.P.; Zhang, F.S.; Zhang, H.; Schröder, J.; Römheld, V. Fertilization and nitrogen balance in a wheat-maize rotation system in North China. Agron. J. 2006, 98, 938-945. [CrossRef]

3. Ju, X.T.; Chen, X.P.; Yin, B.; Zhang, L.J.; Zhang, F.S.; Zhu, Z.-L.; Xing, G.-X.; Christie, P.; Cui, Z.L.; Zhang, S.L.; et al. Reducing environmental risk by improving $\mathrm{N}$ management in intensive Chinese agricultural systems. Proc. Natl. Acad. Sci. USA 2009, 106, 3041-3046. [CrossRef] [PubMed]

4. Gao, W.; Huang, J.; Wu, D.; Li, X. Investigation on nitrate pollution in ground water at intensive agricultural region on Huanghe-huaihe-haihe plain. Eco Agric. Res. 1999, 7, 41-43. (In Chinese)

5. Zhang, X.; Fang, Q.; Zhang, T.; Ma, W.; Velthof, G.L.; Hou, Y.; Oenema, O.; Zhang, F. Benefits and trade-offs of replacing synthetic fertilizers by animal manures in crop production in China: A meta-analysis. Glob. Chang. Biol. 2020, 26, 888-900. [CrossRef] [PubMed]

6. Vitousek, P.M.; Matson, P.A.; Nziguheba, G.; Naylor, R.; Zhang, F.S.; Drinkwater, L.E.; Crews, T.; Holland, E.; Katzenberger, J.; Sanchez, P.A.; et al. Nutrient Imbalances in Agricultural Development. Science 2009, 324, 1519-1520. [CrossRef]

7. Wang, Z.H.; Liu, X.J.; Ju, X.T.; Zhang, F.S.; Malhi, S.S. Ammonia volatilization loss from surface-broadcast urea: Comparison of vented- and closed-chamber methods and loss in winter wheat-summer maize rotation in North China Plain. Commun. Soil Sci. Plant Anal. 2004, 35, 2917-2939. [CrossRef]

8. Chen, X.; Cui, Z.; Fan, M.; Vitousek, P.; Zhao, M.; Ma, W.; Wang, Z.; Zhang, W.; Yan, X.; Yang, J.; et al. Producing more grain with lower environmental costs. Nature 2014, 514, 486-489. [CrossRef]

9. Zhang, Y.; Liu, X.J.; Fangmeier, A.; Goulding, K.T.W.; Zhang, F.S. Nitrogen inputs and isotopes in precipitation in the North China Plain. Atmos. Environ. 2008, 42, 1436-1448. [CrossRef]

10. Zhang, Y.; Luan, S.; Chen, L.; Shao, M. Estimating the volatilization of ammonia from synthetic nitrogenous fertilizers used in China. J. Environ. Manag. 2011, 92, 480-493. [CrossRef]

11. Zheng, X.; Chen, G.; Huang, Y.; Xu, X.; Fu, C.; Hu, F.; Han, S.; Yan, X. The Asian Nitrogen Cycle Case Study. AMBIO A J. Hum. Environ. 2009, 31, 79-87. [CrossRef] [PubMed]

12. Su, C.; Yin, B.; Zhu, Z.; Shen, Q. Ammonia volatilization loss of nitrogen fertilizer from rice field and wet deposition of atmospheric nitrogen in rice growing season. J. Appl. Ecol. 2003, 14, 1884-1888.

13. Matthews, E. Nitrogenous fertilizers: Global distribution of consumption and associated emissions of nitrous oxide and ammonia. Global Biogeochem. Cycles 1994, 8, 411-439. [CrossRef]

14. Galloway, J.N.; Sutton, M.A.; Seitzinger, S.P.; Bekunda, M.; Townsend, A.R.; Martinelli, L.A.; Cai, Z.; Erisman, J.W.; Freney, J.R. Transformation of the Nitrogen Cycle: Recent Trends, Questions, and Potential Solutions. Science 2008, 320, 889-892. [CrossRef] [PubMed]

15. Gruber, N.; Galloway, J.N. An Earth-system perspective of the global nitrogen cycle. Nature 2008, 451, 293-296. [CrossRef]

16. McNeill, A.; Unkovich, M. The Nitrogen Cycle in Terrestrial Ecosystems. Nutr. Cycl. Terr. Ecosyst. 2007, 10, 37-64. [CrossRef]

17. Anderson, N.; Strader, R.; Davidson, C. Airborne reduced nitrogen: Ammonia emissions from agriculture and other sources. Environ. Int. 2003, 29, 277-286. [CrossRef]

18. Cao, Y.; Tian, Y.; Yin, B.; Zhu, Z. Assessment of ammonia volatilization from paddy fields under crop management practices aimed to increase grain yield and $\mathrm{N}$ efficiency. F. Crop. Res. 2013, 147, $23-31$. [CrossRef]

19. Kim, J.Y.; Song, C.H.; Ghim, Y.S.; Won, J.G.; Yoon, S.C.; Carmichael, G.R.; Woo, J.H. An investigation on NH3 emissions and particulate NH 4+-NO3- formation in East Asia. Atmos. Environ. 2006, 40, 2139-2150. [CrossRef]

20. Pinder, R.W.; Adams, P.J.; Pandis, S.N. Ammonia emission controls as a cost-effective strategy for reducing atmospheric particulate matter in the Eastern United States. Environ. Sci. Technol. 2007, 41, 380-386. [CrossRef]

21. Powlson, D.S.; van Kessel, C.; L'hirondel, J.-L.; Addiscott, T.M.; Cassman, K.G.; Benjamin, N.; Avery, A.A.; de Kok, T.M.; van Grinsven, H. When Does Nitrate Become a Risk for Humans? J. Environ. Qual. 2008, 37, 291. [CrossRef] [PubMed]

22. Wang, F.; Dou, Z.; Ma, L.; Ma, W.; Sims, J.T.; Zhang, F. Nitrogen Mass Flow in China's Animal Production System and Environmental Implications. J. Environ. Qual. 2010, 39, 1537-1544. [CrossRef] [PubMed]

23. Chadwick, D.; Wei, J.; Yan'an, T.; Guanghui, Y.; Qirong, S.; Qing, C. Improving manure nutrient management towards sustainable agricultural intensification in China. Agric. Ecosyst. Environ. 2015, 209, 34-46. [CrossRef] 
24. Alburquerque, J.A.; de la Fuente, C.; Campoy, M.; Carrasco, L.; Nájera, I.; Baixauli, C.; Caravaca, F.; Roldán, A.; Cegarra, J.; Bernal, M.P. Agricultural use of digestate for horticultural crop production and improvement of soil properties. Eur. J. Agron. 2012, 43, 119-128. [CrossRef]

25. Alam, S. Production of Organic Manure in Bangladesh; Bangladesh Livestock Research Institute's Report; Bangladesh Livestock Research Institute: Dhaka, Bangladesh, 2006.

26. Chen, G.; Zhao, G.; Zhang, H. Biogas slurry use as $\mathrm{N}$ fertilizer for two-season Zizania aquatica Turcz. in China. Nutr. Cycl. Agroecosyst. 2017, 107, 303-320. [CrossRef]

27. Dahiya, A.K.; Vasudevan, P. Biogas Plant Slurry as an Alternative to Chemical Fertilizers. Biomass 1986, 9 , 67-74. [CrossRef]

28. Lu, J.; Jiang, L.; Chen, D.; Toyota, K.; Strong, P.J.; Wang, H. Decontamination of anaerobically digested slurry in a paddy field ecosystem in Jiaxing region of China. Agric. Ecosyst. Environ. 2012, 146, 13-22. [CrossRef]

29. Sheets, J.P.; Yang, L.; Ge, X.; Wang, Z.; Li, Y. Beyond land application: Emerging technologies for the treatment and reuse of anaerobically digested agricultural and food waste. Waste Manag. 2015, 44, 94-115. [CrossRef]

30. Liu, W.K.; Yang, Q.C.; Du, L. Soilless cultivation for high-quality vegetables with biogas manure in China: Feasibility and beneft analysis. Renew. Agric. Food Syst. 2009, 24, 300-307. [CrossRef]

31. Groot, L.; Bogdanski, A. Bioslurry: Brown Gold? A Review of Scientifc Literature on the Co-Product of Biogas Production; Environment and Natural Resources Series; FAO: Rome, Italy, 2013.

32. Malav, M.K.; Khan, S.; Kumar, S. Biogas Slurry: Source of Nutrients for Eco-friendly Agriculture. Int. J. Extensive Res. 2015, 2, 42-46.

33. Duan, N.; Khoshnevisan, B.; Lin, C.; Liu, Z.; Liu, H. Life cycle assessment of anaerobic digestion of pig manure coupled with different digestate treatment technologies. Environ. Int. 2020, 137, 105522. [CrossRef] [PubMed]

34. Serbian Environmental Protection Agency (SEPA). Standard Methods for the Examination of Water and Wastewater; Version 4; China Environmental Science Press: Beijing, China, 2002.

35. Liu, H.; Li, H.; Zhang, A.; Rahaman, M.A.; Yang, Z. Inhibited effect of biochar application on N2O emissions is amount and time-dependent by regulating denitrification in a wheat-maize rotation system in North China. Sci. Total Environ. 2020, 721, 137636. [CrossRef] [PubMed]

36. Lu, R. Analytical Methods of Soil and Agricultural Chemistry; China Agricultural Science and Technology Press: Beijing, China, 2000. (In Chinese)

37. Abubaker, J.; Odlare, M.; Pell, M. Nitrous Oxide Production from Soils Amended with Biogas Residues and Cattle Slurry. J. Environ. Qual. 2013, 42, 1046-1058. [CrossRef] [PubMed]

38. Shan, L.; He, Y.; Chen, J.; Huang, Q.; Wang, H. Ammonia volatilization from a Chinese cabbage field under different nitrogen treatments in the Taihu Lake Basin, China. J. Environ. Sci. 2015, 38, 14-23. [CrossRef] [PubMed]

39. Wan, X.; Wu, W.; Li, C.; Liu, Y.; Wen, X.; Liao, Y. Soil ammonia volatilization following urea application suppresses root hair formation and reduces seed germination in six wheat varieties. Environ. Exp. Bot. 2016, 132, 130-139. [CrossRef]

40. Xu, J.; Liao, L.; Tan, J.; Shao, X. Ammonia volatilization in gemmiparous and early seedling stages from direct seeding rice fields with different nitrogen management strategies: A pots experiment. Soil Tillage Res. 2013, 126, 169-176. [CrossRef]

41. Yang, Q.; Liu, P.; Dong, S.; Zhang, J.; Zhao, B. Effects of fertilizer type and rate on summer maize grain yield and ammonia volatilization loss in northern China. J. Soils Sediments 2019, 19, 2200-2211. [CrossRef]

42. Beauchamp, E.G.; Kidd, G.E.; Thurtell, G. Ammonia Volatilization From Liquid Dairy Cattle Manure in the Field. Can. J. Soil Sci. 1982, 62, 11-19. [CrossRef]

43. Sommer, S.G.; Genermont, S.; Cellier, P.; Hutchings, N.J.; Olesen, N.E.; Morvan, T. Processes controlling ammonia emission from livestock slurry in the field. Eur. J. Agron. 2003, 19, 465-486. [CrossRef]

44. Sommer, S.G.; Hutchings, N.J. Ammonia emission from field applied manure and its reduction-invited paper. Eur. J. Agron. 2001, 15, 1-15. [CrossRef]

45. Sommer, S.G.; Olesen, J.E. Modelling ammonia volatilization from animal slurry applied with trail hoses to cereals. Atmos. Environ. 2000, 34, 2361-2372. [CrossRef]

46. Bremner, J.M.; Douglas, L.A. Decomposition of Urea Phosphate in Soils. Soil Sci. Soc. Am. J. 1971, 35, 575-578. [CrossRef] 
47. Sommer, S.G.; Schjoerring, J.K.; Denmead, O.T. Ammonia emission from mineral fertilizers and fertilized crops. Adv. Agron. 2004, 82, 557-622.

48. Vlek, P.L.G.; Carter, M.F. The effect of soil environment and fertilizer modifications on the rate of urea hydrolysis. Soil Sci. 1983, 136, 56-63. [CrossRef]

49. Matsushima, M.; Lim, S.; Kwak, J.; Park, H.; Lee, S.; Lee, D.; Choi, W. Interactive effects of synthetic nitrogen fertilizer and composted manure on ammonia volatilization from soils. Plant Soil 2009, 325, 187-196. [CrossRef]

50. Vandrc, R.; Clemens, J.; Goldbach, H.; Kaupenjohann, M. NH3, and N2O Emissions after Landspreading of Slurry as Influenced by Application Technique and Dry Matter-Reduction. I. NH3 Emissions. Z. Pflanz. Bodenkd. 1997, 160, 303-307. [CrossRef]

51. Gu, L.; Liu, T.; Wang, J.; Liu, P.; Dong, S.; Zhao, B.; So, H.B.; Zhang, J.; Zhao, B.; Li, J. Lysimeter study of nitrogen losses and nitrogen use efficiency of Northern Chinese wheat. F. Crop. Res. 2016, 188, 82-95. [CrossRef]

52. Ouyang, D.S.; Mackenuie, A.F.; Fan, M.X. Ammonia Volatilization from Urea Amended with Triple Superphosphate and Potassium Chloride. Soil Sci. Soc. Am. J. 1998, 62, 1443-1447. [CrossRef]

53. Huang, X.; Song, Y.; Li, M.; Li, J.; Huo, Q.; Cai, X.; Zhu, T.; Hu, M.; Zhang, H. A high-resolution ammonia emission inventory in China. Global Biogeochem. Cycles 2012, 26, 1-14. [CrossRef]

54. Zheng, F.; Dong, S.; Liu, P.; Zhang, J.; Zhao, B. Effects of combined application of manure and chemical fertilizers on ammonia volatilization loss and yield of winter wheat. J. Plant Nutr. Fertil. 2017, 23, 567-577. (In Chinese)

55. Cui, Z.; Zhang, H.; Chen, X.; Zhang, C.; Ma, W.; Huang, C.; Zhang, W.; Mi, G.; Miao, Y.; Li, X.; et al. Pursuing sustainable productivity with millions of smallholder farmer. Nat. Publ. Gr. 2018, 555, 363-366. [CrossRef] [PubMed]

56. Zheng, X.; Fan, J.; Cui, J.; Wang, Y.; Zhou, J.; Ye, M. Effects of biogas slurry application on peanut yield, soil nutrients, carbon storage, and microbial activity in an Ultisol soil in southern China. J. Soils Sediments 2016, 16, 449-460. [CrossRef]

57. Du, H.; Gao, W.; Li, J.; Shen, S.; Wang, F.; Fu, L.; Zhang, K. Effects of digested biogas slurry application mixed with irrigation water on nitrate leaching during wheat-maize rotation in the North China Plain. Agric. Water Manag. 2019, 213, 882-893. [CrossRef]

58. Ti, C.; Xia, L.; Chang, S.X.; Yan, X. Potential for mitigating global agricultural ammonia emission: A meta-analysis. Environ. Pollut. 2019, 245, 141-148. [CrossRef] [PubMed] 